\title{
Curculionide.
}

Anthonomus corvulus Lec. Pyrus arbutifolia, Prunus virginiana, H. Cornus alternifolia, W.

A. moleculus Casey. Fragaria virginiana, F.

A. quadrigibbus Say. Prunus virginiana, F.

A. signatus Say. Rubus allegheniensis, $\mathrm{S}$.

Balaninus obtusus Blanch. Cornus, F.

Centrinus scutellum-album Say. Chrysanthemum Leucanthemum, Spiræa salicifolia, $\mathrm{S}$.

Conotrachelus nenuphar Hbst. Prunus virginiana, H. W.

Dorytomus brevicollis Lec. Salix discolor, S.

Gercus picumnus Hbst. Viburnum, Aster, F.

Listronotus appendiculatus Boh. Sagittaria latifolia, W.

Lixus concavus Say. Ranunculus, F.

Madarus undulatus Say. Solidago, F.

Mononychus vulpeculus Fab. Iris versicolor, F. W.

Nicentrus lineicollis Boh. Ceanothus americanus, Solidago, F.

Orchestes pallicornis Say. Amelanchier canadensis, S.

Piazorhinus scutellatus Say. Viburnum, F.

Pseudanthonomus cratogi Walsh. Amelanchier canadensis, Prunus virginiana, F. Rhinoncus pyrrhopus Boh. Rumex acetosella, F.

\section{PARANOMOPONE, A NEW GENUS OF PONERINE ANTS FROM QUEENSLAND. ${ }^{1}$}

\section{By William Morton Wheeler.}

Paranomopone gen. nov.

Worker. Rather small, monomorphic. Mandibles triangular, with toothed apical borders. Clypeus short, not produced in the middle, indistinctly marked off from the remainder of the head. This is also true of the triangular frontal area. Frontal carinæ distinctly dilated, further apart than the distance of each to the lateral border of the head, concealing the insertions of the antennæ, continued back about three-fourths the length of the head as the medial border of a deep scrobe which lies entirely dorsal to the eye. The ventral border of this scrobe, which is somewhat more than three times as long as broad, is also very sharp. Its depression is divided by a median longitudinal ridge which does not extend to the posterior end of the scrobe, so that the latter is incompletely separated into two compartments, one for the accommodation of the scape and one for the funiculus, when

\footnotetext{
${ }^{1}$ Contributions from the Entomological Laboratory of the Bussey Institution, Harvard University, No. 93.
} 
the antenna is folded back against the head. Eyes small, situated behind the middle of the head. Ocelli absent. Antennæ 12-jointed, funiculus somewhat enlarged at the tip into a 3-jointed club, which, however, is not very sharply marked off from the more basal joints. Palpi extremely short. The number of their joints could not be ascertained. Thorax small and short, with a very distinct promesonotal but no mesoëpinotal suture; epinotum unarmed. Petiole nodiform, attached to the postpetiole by a very small, narrow surface. Postpetiole voluminous, larger than the first gastric segment, constricted behind, remaining gastric segments very small, almost completely telescoped into the first segment. Sting well-developed. Legs rather stout and short; hind tibiæ each with a single large, richly pectinated spur; tarsal claws simple, slender and straight. Sculpture and pilosity rather coarse.

Female. Ergatoid and differing from the worker only in having an anterior ocellus and in the larger size of the postpetiole and first gastric segment, and in the latter being as large as the former.

\section{Paranomopone relicta sp. nov.}

Worker. (Figs. 1-4). Length 4-4.5 mm.

Head, excluding the mandibles, scarcely longer than broad, distinctly narrower in front than behind, with broadly and rather deeply excised posterior border and prominent posterior corners, its sides rather straight, its upper surface convex, the gula flattened. Mandibles with slightly convex external borders and about 7-8 subequal teeth on the apical borders. Clypeus flat, with a sharp median carina, anteriorly very slightly projecting as a short lobe with straight median border and rounded corners. Antennal scapes about three-fourths the length of the head; first funicular joint about as long as broad: joints 2-8 decidedly broader than long; first and second joints of club subequal, each about as long as broad and together distinctly shorter than the terminal joint. Thorax narrower than the head, broadest through the pronotum, which, seen from above and excluding the neck, is nearly twice as broad as long, broadest in front, with the humeral and inferior angles sharp and pointed. Promesonotal suture very sharp and distinct; mesoëpinotum from above less than twice as long as broad, its sides feebly concave, in profile scarcely longer than high, with the base of the epinotum convex and somewhat longer than the declivity, which is concave and sloping and has a distinctly crenulate margin on each side. Petiole from above broadly elliptical, slightly broader than long, with rounded sides; in profile as high as the thorax, about one and three-fourths times as high as long, with straight and perpendicular anterior, convex and horizontal superior and concave and perpendicular posterior surface. Ventral surface with a small tooth near its anterior border. Postpetiole from above and from the side rounded, as broad as long, broader and longer than the first gastric segment, which is rather cylindrical and encloses the small remaining gastric sements. There is a small blunt tooth at the anterio-ventral margin of the postpetiole.

Rather shining; mandibles smooth, sparsely and rather coarsely punctate. Clypeus with a few sharp longitudinal rugæ on the sides. Head between the frontal carinæ and medial borders of the scrobes traversed by about seven sharp longitu- 
dinal rugæ on each side of the median line, which is itself represented by a ruga continuous anteriorly with the median carinula of the frontal area and the clypeal carina. The rugæ diverge on each side of the middle line and there are shallow, elongate punctures in the interrugal spaces. Cheeks also with similar, but more reticulate, coarse rugæ. On the occiput and posterior corners of the head the longitudinal rugæ are replaced by very coarse punctures or foveolæ, so close together that the spaces separating them are converted into reticulate rugæ. Thorax, petiole, postpetiole, and first gastric segment finely punctate and covered with foveolæ similar to those on the occiput but distinctly sparser on the postpetiole and gaster. Epinotal declivity, posterior declivity of petiole, scrobes of the head and a portion of the mesopleuræ glabrous and very shining, the scrobe also slightly striolate. Antennæ, legs and terminal gastric segments subopaque, finely and densely punctate.

Hairs and pubescence rather coarse, grayish yellow; the former long, erect, of unequal length, covering the body, legs and scapes and quite as long on the extensor surfaces of the appendages as on the body. Pubescence long and appressed on the body, most distinct on the gaster and postpetiole, finer and denser on the legs and antennal scapes.

Head, thorax and petiole dark brown or piceous above; mandibles, clypeus, antennæ, pleuræ, legs, sides of petiole and the whole of the postpetiole and gaster richer brownish red.

Female. (Figs. 5 and 6.) Length $5.5 \mathrm{~mm}$.

Differing from the worker only in the shape and size of the abdomen, the postpetiole and first gastric segment being larger and the latter as broad as the petiole and fully as broad as long. These segments are of the same dark brown color as the head and thorax, whereas the remaining gastric segments are paler brownish red, like the legs, antennæ and mandibles.

Described from a single female and two workers taken October 28, 1914, under a large rotten log in the moist tropical "scrub" at Kuranda in Northern Queensland. These specimens with a few nearly full-grown larvæ apparently comprised the whole colony. The larva (Figs. 7 and 8) is rather slender, pure white and covered with delicate white hairs, which are short and rather dense, especially on the dorsal surface, and interspersed with fewer, longer and more flexuous hairs. The head is rounded, sparsely hairy and bears a pair of well-developed, tridentate mandibles.

Paranomopone has all the ear-marks of being a very ancient, possibly Mesozoic genus, which still survives as a very rare relict in tropical Queensland. It is difficult to assign it to a definite position in any of the existing tribes of the subfamily Ponerinæ as enumerated and defined by Emery in the "Genera Insectorum." In the structure of the thorax and abdomen there is considerable resemblance to the peculiar Haytian genus Emeryella Forel among 
the Ectatommiini, but the deep scrobes of the head are unlike anything seen in other known Ponerine genera. Paraponera, to be sure, has scrobes, but these are of a very different conformation, being angulate and enclosing the eye in such a manner that the scape lies over, and the funiculus under the eye, when the antenna is folded back against the head, whereas in Paranomopone the whole scrobe is above the eye. In other respects the head shows close affinities with the Ectatommiini, so that, on the whole, I am inclined to assign it to this tribe. The peculiar ergatoid female is of unusual interest in connection with similar females of the genera Onychomyrmex and Leptogenys and the apparent absence of definite female forms in some of the other Australian ant-genera, notably Rhytidoponera sens. str., Diacamma and Leptomyrmex.

\section{EXPLANATION OF THE PLATE.}

Fig. 1. Paranomopone relicta sp. nov. Worker in profile.

Fig. 2. Head of same seen from above.

Fig. 3. Thorax and abdomen of same seen from above.

Fig. 4. Antenna.

Fig. 5. Female (ergatoid), in profile.

Fig. 6. Thorax and abdomen of same seen from above.

Fig. 7. Nearly full grown larva.

Fig. 8. Head of same from above.

\section{NOTES ON THE EXTERNAL ANATOMY OF BOREUS BRUMALIS FITCH. ${ }^{1}$}

\section{By S. M. Dohanian.}

In December, 1914, and January, 1915, a score or more of Boreus brumalis Fitch were found by Mr. Richard Mead in Weston, Mass., near the base of an oak tree. Another was found by the writer during the latter part of January in the Arnold Arboretum, Jamaica Plain, Mass., on melting snow near a brook. Investigation of this curious and interesting insect has called attention to

\footnotetext{
1 Contributions from the Entomological Laboratory of the Bussey Institution, Harvard University, No. 97.
} 


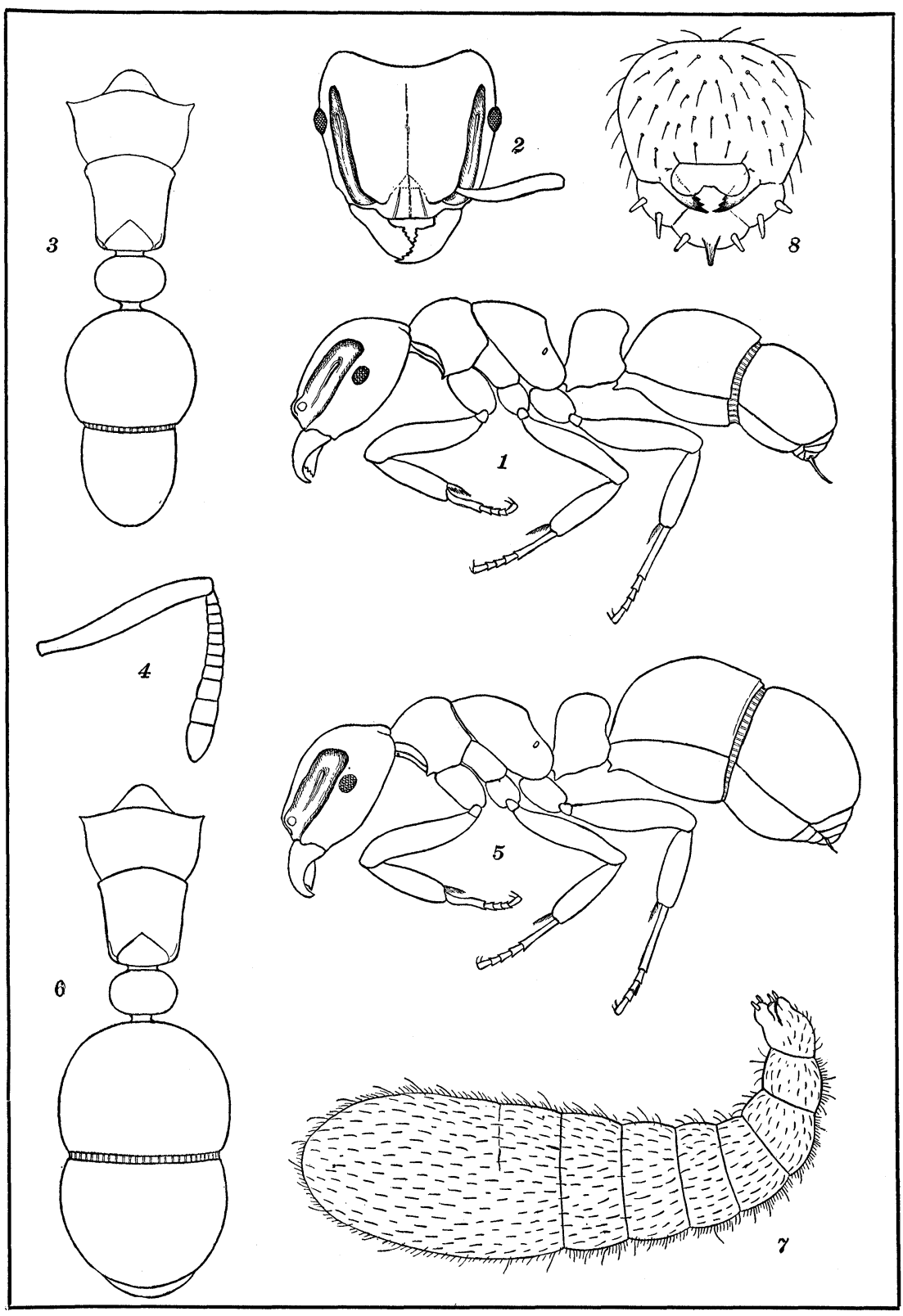

WheELER-Paranomopone. 

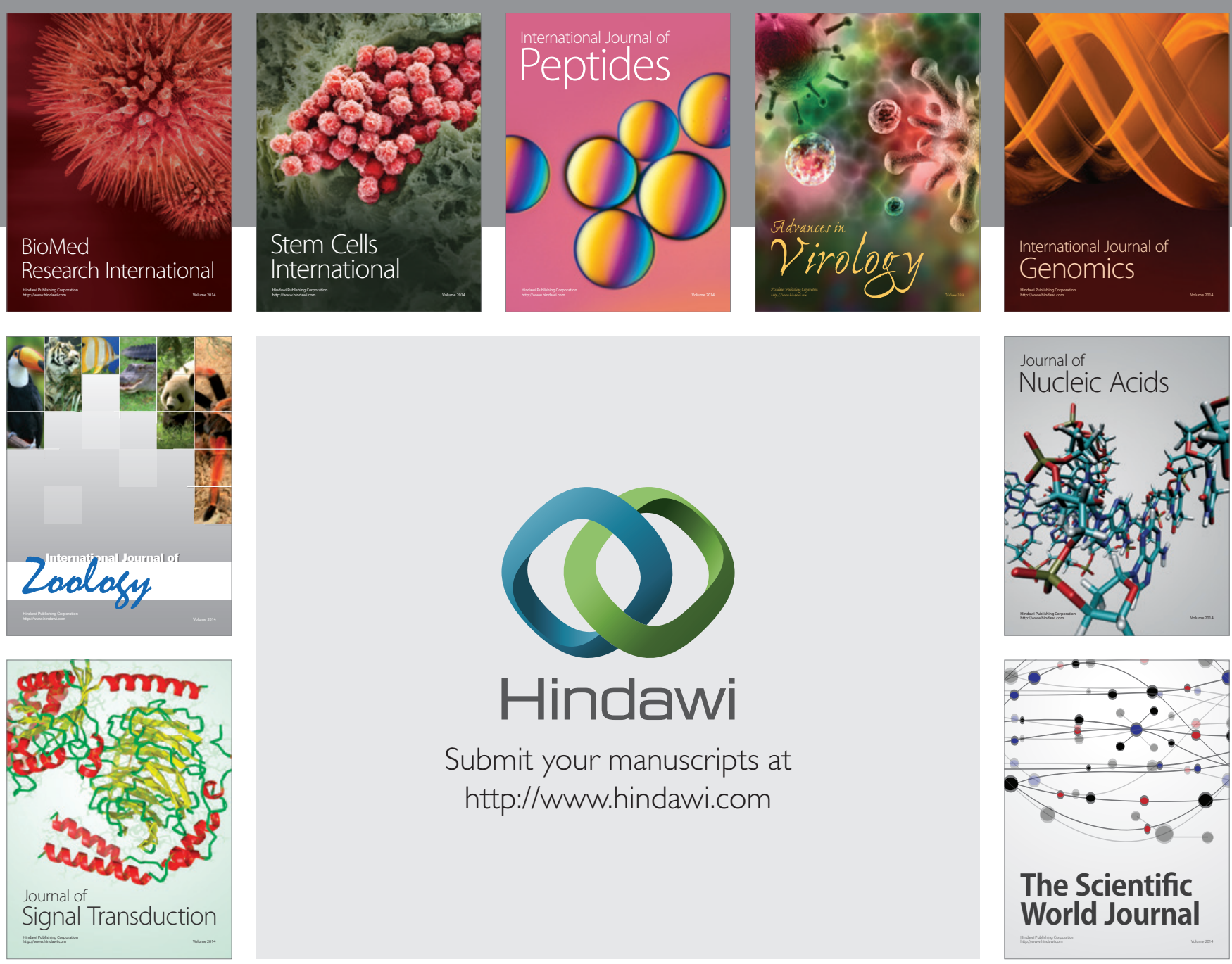

Submit your manuscripts at

http://www.hindawi.com
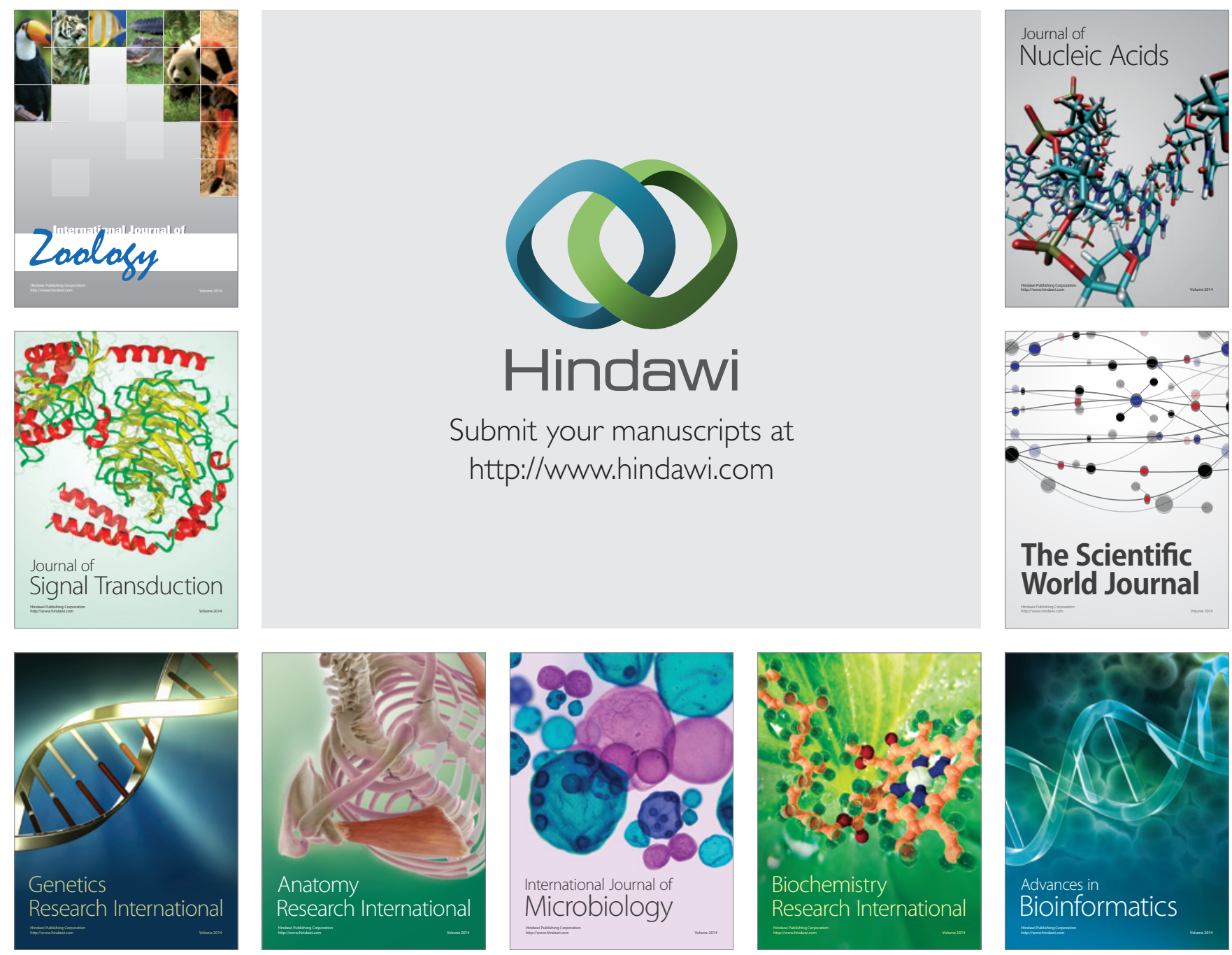

The Scientific World Journal
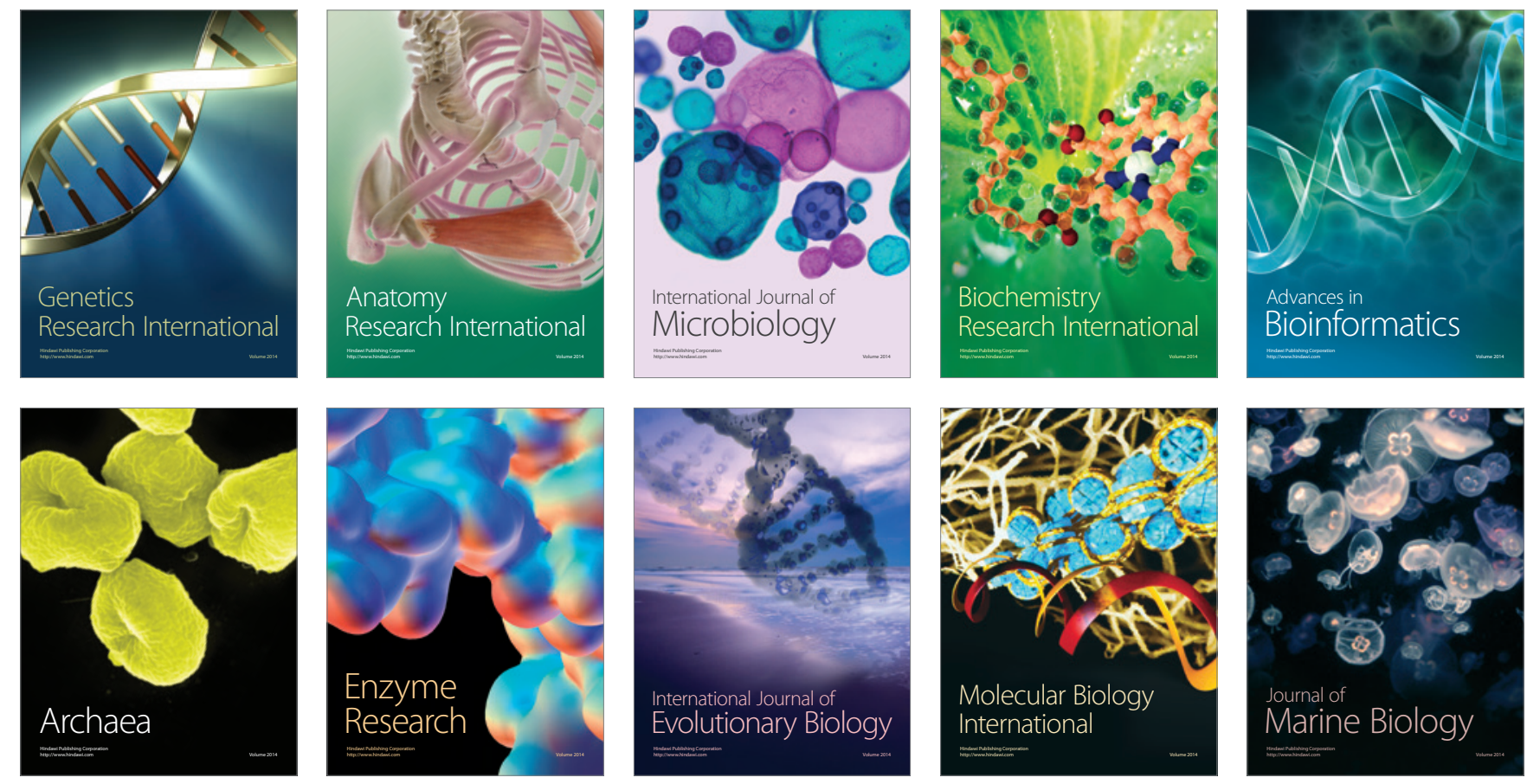